\title{
Democracy, Autocracy, and Emergency Threats: Lessons for COVID-19 From the Last Thousand Years
}

\author{
David Stasavage $\odot$
}

\begin{abstract}
Our experience with COVID-19 has yet to show that either democracies or autocracies are unambiguously better at dealing with this threat. What the pandemic has instead demonstrated is that these two forms of government each have specific strengths and weaknesses when it comes to dealing with external emergencies. In autocracies centralization of power allows for decisive action, but their ability to maintain secrecy means that they can also suppress information and ignore a problem. In a democracy greater transparency makes it hard to cover up a threat, but the decentralization of power that is inherent to a democracy can lead to a slow and potentially ineffective response. Using both current and historical comparisons between China and western countries, I show that these different patterns have deep roots, dating back a thousand years or more. I then consider three alternative proposals for democracies to be able to act more decisively: allowing for rule by decree, devolving responsibility to localities, and investing in preventative state capacity. History shows that the latter of these three is the safest and most effective strategy, but for it to work voters must reward politicians for investing in prevention. Unfortunately, this reward cannot be assumed.
\end{abstract}

The COVID-19 pandemic may seem like an unprecedented challenge to both democracies and autocracies. It's actually an old problem in a new guise. Throughout history societies have faced the question of how to respond to emergency threats from abroad. These threats have come in the three categories of war, famine, and pestilence-sometimes known as the last three of the four horsemen of the apocalypse. ${ }^{1}$ As societies encountered these threats, they also faced crucial questions about the relative benefits of autocracy versus democracy in dealing with emergencies. In what follows I draw on several of the lessons from my recent book to show what history has to say about this issue. ${ }^{2}$

Editor's note: This article is part of an online supplemental issue on COVID-19 and international relations. The authors were invited by IO's editorial team and guest editor Michael C. Horowitz. The manuscript was reviewed based on written non-anonymous reviewer comments and during an online workshop. The revised manuscript was evaluated by the $I O$ editorial team. We appreciate the support of Perry World House at the University of Pennsylvania for making this possible.

1. This is the interpretation given by the Encyclopedia Britannica based on Revelation 6:1-8, though there are also other interpretations.

2. Stasavage 2020. While my investigation here will be an empirical one, I should note that there is also an extensive and important literature in political theory that considers the question of how democracies 
I propose first that we can learn a great deal about the politics of emergency by comparing China and the West, then and now. The comparison will therefore be between western countries and the prime example of an autocratic regime with high state capacity. Over the last few months many have contrasted the effectiveness of China's COVID-19 mitigation efforts with the way that the federal government in the United States failed to take decisive action. This makes it feel like a point scored for the authoritarians. But there are other ways in which the Chinese Communist Party's response to the crisis was clearly ineffective. Suppression of information allowed the Wuhan outbreak to occur in the first place. In the United States, though the Trump administration chose to ignore the pandemic for a long time, information about it circulated widely and freely. This would seem like a strength of democracy.

I argue that the differences in COVID-19 responses that we are seeing today are not new, nor are they attributable to the particular personalities of Donald Trump and Xi Jinping. They are in fact very deeply rooted in history going back a thousand years or more. We can see this by looking not only at epidemics but also at historical evidence on famines - an emergency associated with another of the four horsemen. A thousand years ago the Chinese state had the ability to respond to famines, but it could also ignore them. States in medieval Europe, where decision making was collective with rulers and representative assemblies, could not suppress information about a famine, but nor could they do much to deal with the problem.

The conclusion I draw is that rather than asking whether it is the democracies or the autocracies that do better in handling threats-and there is an abundant international relations literature on this subject-we ought to instead be considering the specific strengths and weaknesses of each of these two forms of government. ${ }^{3}$ Autocracies with high state capacity are capable of swift action, but they can also suppress information about an emergency or resist popular demands for a response. Democracies are the flipside of this. It is harder for them to suppress information or to ignore popular demands to do something, but the inherent decentralization of power in a democracy can lead to a slow response.

I next consider how democracies can best take decisive action in response to an emergency. Here history suggests that there are three options. The first is for a democracy to temporarily grant someone emergency powers, and the most famous historical example of this is the practice of dictatorship under the Roman Republic. The risk of doing this is that emergency powers could be abused and made permanent. The second option-and this is the safest one for democracy-is to leave it to states and localities to deal with emergencies, but as we are seeing with COVID-19,

cope with emergencies. See in particular Lazar 2009 and 2006; Honig 2009; and Manin 2008. The early foundational (and controversial) work on emergency powers under democracy was done by Schmitt 1921.

3 . For a recent contribution on democracies, autocracies, and war with reference to the COVID-19 pandemic see Reiter and Stam 2020. They argue that evidence from a century or more shows that democracies are more likely to win wars when engaged against autocracies, and the same may hold true in the fight against disease. See Bosancianu et al. 2020 as well as Cheibub, Hong, and Przeworski 2020 for recent empirical evidence on state characteristics and COVID-19. 
local action on its own may not suffice. We will also see one historical example where a republic failed because it left too much to the localities. The third option is to invest in state capacity that can be used for prevention while strictly limiting emergency powers. The question then becomes whether the electoral process will give politicians an incentive to make these investments. Unfortunately, existing empirical evidence suggests that when it comes to elected officials-and the voters who choose whether to retain them - we may need to stand Benjamin Franklin's maxim on its head: an ounce of cure is worth a pound of prevention.

\section{How Different Types of Governments Are Dealing with the COVID-19 Pandemic}

Many recent observers have asked whether a comparison of Chinese and western responses to the COVID-19 pandemic provides broader lessons about the ability of democracies-as opposed to authoritarian states-to respond to emergencies. To consider this we need to take each group separately before then asking where these differences come from.

\section{Autocracies in the Current Emergency}

The initial news about COVID-19 seemed to cast the Chinese system of government in a bad light. Early news about the new virus in Wuhan and the surrounding province of Hubei was suppressed, and no efforts at containment were made, policies that allowed the virus to infect many more people than would have otherwise been the case. Some American observers called this the greatest challenge that the Chinese Communist Party (CCP) had faced in decades. ${ }^{4}$ For believers in democracy it seemed to point to the inevitable superiority of their system of government. ${ }^{5}$ It is hard to deny that if what happened in Wuhan had instead happened first in a large American city, the news could not have been suppressed. Democracies like the US are very porous.

What happened next in China seemed to turn the tables on the idea that a democracy could handle a pandemic better, though some did not initially realize that this would be the case. As early as 7 January, the Standing Committee of the Politburo of the CCP adopted the principle of fangkong, or "prevention and control" to deal with the COVID-19 crisis, and this principle was subsequently made public. As Sheena Chestnut Greitens has recently shown, though the CCP is now using fangkong as a public health term, it has a deeper history of use in reference to security problems within an authoritarian state. ${ }^{6}$ 
The principle of fangkong was soon put firmly to work: on 23 January 2020 the Chinese government imposed a lockdown on Wuhan and all large cities in Hubei province. It was what one American medical historian called "the mother of all quarantines." The day after the quarantine was announced some Western observers were critical, suggesting that it would create distrust among the affected population and that it would be "likely to drive the pandemic underground." In addition to imposing the strict quarantine, the Chinese government adopted a policy of extensive testing, isolation of those with the disease, and a strict nationwide policy of social distancing. A World Health Organization (WHO) report released on 28 February lauded the Chinese response in limiting the spread of the disease. ${ }^{8}$ Since that point the COVID-19 death toll in many Western countries has been larger by an order of magnitude or more when compared to China.

The Chinese Communist Party's response to COVID-19 differed dramatically from what it did during another emergency some sixty years ago. In 1958 the CCP launched the Great Leap Forward, the core of which was a total collectivization of agricultural production. This turned out to be a failure that resulted in massive shortfalls in agricultural production and a famine in which millions died. In this case the CCP chose to suppress not only the early signals of famine but also all subsequent ones, even though they were hotly debated within senior party ranks. ${ }^{9}$ It is possible that sixty years ago it was easier to suppress information in a country where the immense majority of the population lived in villages with little outside contact. ${ }^{10}$

If the eventual Chinese response to COVID-19 clearly proved effective, the next question is whether this is explained by the fact that China is an autocracy, or whether it instead derives from some other attribute of Chinese society. One reason to think that autocracy made the difference is that a very strict quarantine could be imposed without consideration for potential human rights concerns or civil liberties. There was no need for the CCP to prove that what it was doing was legal or that it adhered to some fundamental constitutional precept. There was no risk of a court challenge or of protestors demonstrating against it. Implicit in all this was the fact that China had the state capacity to implement this response.

Evidence from other authoritarian regimes suggests similar conclusions to the ones I have just drawn for China. Authoritarian regimes can be remarkably swift in controlling the spread of the virus, but they can also be very effective in suppressing information about it. In cases like Vietnam and Singapore, governments responded quickly to the COVID-19 threat. In Vietnam's case this was done through a very

7. This view was provided by Lawrence O. Gostin, a university professor of law at Georgetown. The quote on the "mother of all quarantines" is from a medical historian named Howard Markel; see Bernstein and Craig 2020.

8. Kupferschmidt and Cohen 2020.

9. This occurred most notably at a conference held at Lushan in the Summer of 1959. Mao Zedong's principal critic at this conference, Peng Dehuai, was subsequently purged from all positions within the party; see Jisheng 2012, 355-369.

10. See Jisheng 2012, 8. 
early effort to close all border links with China, through closure of schools, and by referring to the fight against the virus in terms of the Spring offensive of 1975 against South Vietnam. In the case of Singapore, the virus was controlled through very extensive monitoring and contact tracing. But in other cases, authoritarian regimes have also excelled at an alternative tactic: ignore the problem and suggest that someone else is responsible. In Russia, Vladimir Putin, after a quick initial response, decided to ignore the COVID-19 problem, suppress information about it, and leave it to regional governors to manage the crisis. ${ }^{11}$

What can we say of the many autocratic regimes that have low levels of state capacity? From the point of view of COVID-19, a regime like this should be the worst of both worlds. As an autocracy it could try to ignore the problem, say by controlling the media, but it would also lack the capacity to do anything durable to prevent viral spread. Burundi provides an example of the former tendency as efforts to ignore the pandemic extended even to expelling WHO officials from the country. The pandemic did become harder to ignore when the country's outgoing president died from the disease. The Philippines demonstrates the latter tendency. In this country with relatively low administrative capacity that the Varieties of Democracy project classifies as an "electoral autocracy," it was still possible to impose a severe lockdown where President Rodrigo Duterte said of violators "shoot them dead," but a durable response along the Chinese model was not feasible. This would have involved extensive testing, tracking, and tracing. ${ }^{12}$

\section{Democracies in the Current Emergency}

Now consider the United States federal government's response to COVID-19. Much of the criticism here has been laid at the feet of President Donald Trump, and it's hard to contest this point. In spite of both private and public warnings about the danger posed by COVID-19, the president adopted the hopeful assumption that this would simply all go away. In fact, the United States has not only done worse than China, but also worse than most other western democracies.

One of the questions we need to ask about the federal government's response to COVID-19 is would things really have been so different if there were someone else in the White House? To make this case we would need to be able to demonstrate that the federal government would have had the capacity to respond early and aggressively to COVID-19. One obstacle here is the inherent decentralization of power in American democracy. The precise idea of a democracy - and this has been the case for a very long time-is that the capacity of the center ought to be limited. In the United States we have a particularly accentuated version of this, not just because of our federal system, but more deeply because of colonial heritage. When 
English settlers established the original thirteen colonies they did so with a set of dispersed local communities and a virtual absence of central state coercive power. This gave birth both to a fear of strong central control and to the idea of a spirit of rugged individualism. ${ }^{13}$ The consequence has been a continued dispersion of power. The conclusion one could draw is that American democracy—almost as if by designis not particularly well equipped to deal with a pandemic.

Does the experience of other democracies in dealing with COVID-19 resemble that of the United States? Some democracies, such as South Korea, Taiwan, and Germany, have been much more effective at dealing with the virus thanks to very early implementation of testing and contact tracing. In South Korea and Taiwan this may be attributable to more centralized decision making than in the United States, though I will also identify a further important reason: prior lessons learned from the SARS and MERS outbreaks led governments to invest in preventative state capacity. ${ }^{14}$ Germany stands out as a case of a country with a federal system that did very well against the virus.

In countries like Taiwan, South Korea, and Germany an early focus on prevention helped prevent the need for the sort of extensive restrictive measures for which authoritarian states have a comparative advantage. In other cases-and one thinks here of France, Italy, Spain, and the United Kingdom-a failure to engage in early prevention meant that governments then had to impose costly nationwide lockdowns. But with COVID-19 these democratic states were at a comparative disadvantage relative to an authoritarian regime like China.

The picture I have presented here does not suggest that democratic governments have inevitably done worse than authoritarian governments when dealing with COVID-19. What I have instead tried to argue is that these two types of political regimes face different pathologies when it comes to dealing with the emergency. Authoritarian states that have a high level of state capacity are unhindered in implementing forceful measures, but the very nature of authoritarian control also means that public pressures to quickly respond to an emergency are weaker. Democracies face the opposite challenge. Given the nature of information flows, it is harder to keep the public in the dark about an emergency. At the same time, the inherent decentralization of power in a democracy can make swift and decisive action more of a challenge. In what follows I argue that the differences between how autocracies and democracies respond to emergencies have very deep historical roots.

\section{Collective and Autocratic Governments in Past Emergencies}

The different responses to COVID-19 that we see in democracies and autocracies, East and West, cannot be explained just by current circumstances or personalities. They have deep historical roots. 
When it comes to earlier epidemics, for China we have records of the use of central state-imposed travel bans for disease containment as early as $1187 \mathrm{CE} .^{15}$ The bureaucracy of the Song Dynasty would have allowed for this in the same way that the CCP bureaucracy has done more recently. For England records of quarantine regulations begin substantially later, under King Henry VIII, and they appear to have consisted largely of localized measures without strong central control. ${ }^{16}$ The exception in Europe was with the city-states where Venice pioneered the concept of quarantine in Europe and gave us the word itself. ${ }^{17}$

The one problem with looking at historical epidemics is that though prior to the modern era, rulers from both East and West had hit on the idea of isolating the sick from the healthy, without a modern concept of disease transmission the ability of all states to deal with an epidemic was fundamentally limited. One way to approach the question then is to consider a different type of emergency that was better understood and over which governments might have had more control: famine. ${ }^{18}$

Consider a tale of two different famines, one in China in the year $1012 \mathrm{CE}$ and one in England in the year 1315. China at this time was a centralized autocracy. England in 1315 was most certainly not a democracy in the modern sense, but it did have an active parliament and therefore a much more collective and consensual form of government than China.

In China in $1012 \mathrm{CE}$ there was a famine in the Yangtze Valley linked to the failure of the rice crop due to drought. ${ }^{19}$ What happened next reveals the remarkable capacity of the Chinese state and its ability to use this to address an external emergency. Thanks to the Chinese Empire's vast extent and connections with other kingdoms, emperor Zhenzong of the Song Dynasty became aware of a variety of rice that was both drought-resistant and quick to ripen. This rice variety-originally sent by emissaries from the Champa Kingdom in central Vietnam-had been grown in Fujian province for several decades. Seeing an opportunity, the emperor obtained thirty thousand bushels of seeds of what would become known as "Champa rice." He sent the seeds to the areas stricken by drought, together with government officials to train farmers to grow the rice. The result was a greatly relieved famine. One suspects that thanks to China's system of government, the emperor did not need to bargain for the rice seed on the open market.

The story of emperor Zhenzong sounds like a happy version of autocratic paternalism. Unfortunately, just as in the People's Republic in more recent times, it did not always work this way in Imperial China. Just like today, rulers sometimes ignored or suppressed information about emergencies. In the year $862 \mathrm{CE}$, near the end of the

15. Dunstan 1975.

16. Roger 2019.

17. See Gensini, Yacoub, and Conti 2004 for the full story.

18. It is useful to look at cases of famine because states at this early date could in theory do something about it through crop management, the distribution of food, and the regulation of markets.

19. See Barker 2012 on the Champa rice and Ho 1956 for detail on the historical episode. This is also covered in Stasavage 2020, 184. 
Tang Dynasty, there was famine in the provinces of Huainan and Henan thanks to a lethal combination of drought and locusts. In this case no one rode to the rescue. The Emperor Yizong instead continued to requisition foodstuffs from Huainan and Henan to supply southern armies. ${ }^{20}$ Authoritarian rule allowed the Chinese state to ignore a famine, just as Amartya Sen has suggested it did in more recent emergencies of this type..$^{21}$ In the two largest famines of the twentieth century, in China during the Great Leap Forward and in the USSR during the forced collectivization of agriculture, states knew about famines yet did nothing, and their policies actually created the problem in the first place. ${ }^{22}$

Now consider the case of a famine in a world region with a more collective form of governance. A great famine took place throughout Western Europe beginning in the year 1315. Cold temperatures and excessive rain led to massive crop failures and subsequent food shortages. This, in fact, signaled the end of an era that climatologists now refer to as the Medieval Warm Period.

Outside of its autonomous cities, Western Europe at this time lacked anything resembling the levels of state capacity that existed in China. The rulers of European territorial states were kings, but they had no bureaucracies that would allow them to rule effectively as autocrats. The kings of England and France each had only a few dozen officials under their direct command. ${ }^{23}$

What many-in fact most-Western European states did have were representative institutions that differed radically from anything that existed in China. Lacking bureaucratic states, kings were forced to rule collectively with members of society who sat in these councils or assemblies. It was often left to these same representatives to implement core activities like the collection of taxes. As in our democracies today, there was a significant—even an extreme—degree of decentralization in this early era.

England's king at this time, Edward II, is someone to whom posterity has not been kind. He has been criticized for his weak leadership and errors of judgement. Edward's counsellors attempted to portray him as acting like Pharaoh when he put Joseph in charge of the granaries of Egypt, but no one believed it. One modern historian's assessment of Edward II and the famine is that he "failed in famine relief" and "failed to cover up his failure." 24

In the end there were deep structural reasons that would have made Edward's famine relief efforts a failure no matter what his personality was like. If we compare him to emperor Zhenzong, who had the power to commandeer large stocks of seed and transport them from one province to another, then we must conclude that Edward had nothing even faintly resembling this degree of authority. Though he was indeed a king, he needed to contend with barons and individual

\author{
20. Somers 1979, 696. \\ 21. Sen 1981. \\ 22. For the comparative data, see Hasell and Roser 2013. \\ 23. Stasavage 2020, chapters 5 and 9. \\ 24. Jordan 1996, 177.
}


localities in Parliament who all could set local policies independently from royal control. Edward could attempt to place restrictions on prices while also seeking to limit exports of grain, but he had little in the means of a state apparatus to ensure that these policies were respected. In the end, one has the impression that England's grain merchants did largely as they pleased.

In sum, just as in modern societies with collective governance, there was no way that Edward II could have simply ignored the Great Famine, but he also faced obstacles in acting decisively. In modern Western democracies central state power has grown much stronger than it was in Edward's day. Even so, the pattern of decentralized power continues to be a deep structural feature, making decisive action more difficult. What we need to consider next then is how a democracy could overcome this hurdle.

\section{How Can a Democracy Best Deal with an Emergency?}

We can consider three alternative possibilities for a democracy to deal with an emergency. The first is to grant extraordinary emergency powers to a central leader. The second is the opposite course: rather than strengthen central power, leave it to individual localities to cope with the emergency. In what follows I will suggest that except in specific circumstances, neither of these first two options is particularly enticing. This leaves a third possibility: avoid emergency powers but build preventive state capacity. This can be done as long as the public does indeed reward leaders for taking preventive action, but that is not a given.

\section{Option One: Constitutional Dictatorship}

In 1948 Clinton Rossiter, who would become one of the most eminent political scientists of his generation, wrote the following: "No form of government can survive that excludes dictatorship when the life of the nation is at stake." ${ }^{25}$ Rossiter clearly intended this statement to be provocative. What he meant is that from time to time, all democracies will face emergencies where the ordinary constitutional process for making decisions and protecting individual liberties is not effective. Paradoxically, the only way to safeguard democracy is to temporarily suspend it.

Scholars who write about the importance of granting emergency powers often use the example of dictatorship under the Roman Republic as a case in point. The Roman practice of constitutional dictatorship-which differed considerably from the much later practice of permanent dictatorship promoted by Julius Caesar-was one where the senate and consuls temporarily gave power to an individual granted exceptional authority over a specific matter. This individual's authority was restricted in two ways: it concerned only the matter at hand, and it was temporally limited. 
Though opinions vary, the most in-depth recent historical account suggests that the Roman dictatorship functioned well in the way originally intended for a period of three centuries during the Republic. Individuals were chosen to deal with a specific emergency, and after they dealt with it they resigned. ${ }^{26}$

While the Roman model of a dictator has not been repeated, it has certainly provided much inspiration. Written constitutions in more recent republics have at times allowed not for a temporary change in leadership, but instead for granting special powers to an existing leader. The powers could be used to address external threats, insurrection, or economic and social crises. One of the most prominent features of emergency powers in modern democracies has been to give executives under certain circumstances the right to rule by decree. The motivation for these provisions has been the same as the original Roman model of temporary dictatorship. Under certain circumstances it is thought to be useful to give a chief executive the right to act with speed and without being burdened by the traditional legislative process.

The big problem with emergency powers of this sort in modern democracies is that they have been ripe for abuse. They also have not repeated the success of the original Roman model.

One of the most notorious examples of emergency powers gone awry involved Article 48 of the constitution of the Weimar Republic in Germany (1919-1933). ${ }^{27}$ This gave Germany's president the ability to rule by decree if the article was invoked. During the economic crisis that Germany suffered throughout this period, presidents unable to obtain a majority for their economic plans began to use Article 48 with increased frequency, making its usage seem more mundane. After the elections that saw Adolf Hitler become chancellor as well as the subsequent Reichstag fire of February 1933, under the auspices of Article 48, Germany's president, Paul von Hindenburg, issued a decree enacting severe constitutional restrictions. By using Article 48, Adolf Hitler had effectively become a dictator through constitutional means.

The abuse of emergency powers is not only of historical interest: the practice is alive and well in the COVID-19 era. In Hungary, Viktor Orban, completing a set of autocratic "reforms" thanks to COVID-19, now has the power to rule extensively by decree. ${ }^{28}$ In Cambodia a new emergency law has allowed premier Hun Sen to monitor and control all individual communications while also strictly controlling the media in order to deal with COVID-19.29 It would seem that for both would-be and established autocrats COVID-19 could not have come at a better time, and there are many other examples one could cite. ${ }^{30}$

26. Wilson 2017. See Manin 2008 and Rossiter 1948 for a comparison of Roman practice with more recent versions of emergency powers.

27. Carl Schmitt 1921 looked with favor upon Article 48.

28. Zerofsky 2020.

29. Ratcliffe 2020.

30. See Greitens 2020 for an insightful review of further examples of adoption and abuse of emergency powers. 
Ultimately, there is one way that emergency powers could be used successfullywithout danger to democracy-against a threat like COVID-19, but this does not involve rule by decree. After their experience with the SAR and MERS outbreaks, Taiwan and South Korea adopted new legal frameworks that allowed for the temporary granting of special powers that would aid especially with tracing and tracking individuals so as to limit viral spread. In some ways these special powers more closely resemble the nature of the early Roman dictatorship: as argued by Sheena Chestnut Greitens, they were proportional, temporally limited, and ultimately subject to legislative or judicial oversight. ${ }^{31}$

\section{Option Two: Leave it to the Localities}

One of the most salient features of the current COVID-19 pandemic in the United States is that Americans trust their state and local governments more than they trust the federal government to deal with the crisis. ${ }^{32}$ This is particularly true if the federal government is thought of as everything "in Washington" as opposed to more specialized federal agencies. So if states and localities are doing so much better than the federal government at handling things, then maybe the federal government should simply get out of the way? One editorialist recently suggested precisely this. ${ }^{33}$ This would fit with the longstanding idea that the heartbeat of American democracy comes from local community action.

While leaving it to the localities seems like a nice idea, the problem with this solution is that there are some emergencies for which the decentralized approach does not work well. For example, it can actually be useful to have a federal stockpile of personal protective equipment (PPE) so that nurses do not have to wear garbage bags. ${ }^{34}$ Absent central investments in the ability to ramp up testing and tracing cases of a disease, there is a greater risk of spread from one locality to the next without it being known. The United States is not the only country in which a decentralized form of democracy has posed challenges for dealing with COVID-19. Even in cases like Germany - where the response to COVID-19 has been much more successful - the pandemic has nonetheless placed great strain on the country's constitution. ${ }^{35}$ Remembering the failed emergency powers of the Weimar Constitution, Germans in 1949 chose a Basic Law that restricts central power, but under this law it has been difficult to declare even COVID-19 an emergency because of questions of where authority lies between the federal government, state governments, and the localities.

It is in fact possible for a republic_even a great one-to fail as a result of leaving too much to the localities. To see this, we need look no further than the Netherlands.

31. Greitens 2020.

32. Blake 2020.

33. Stephens 2020.

34. Fottrell 2020.

35. Stelzenmüller and Denney 2020. 
In the seventeenth century the Dutch Republic was one of the dominant military powers of its day, and it also had what economic historians have called the "first modern economy." ${ }^{36}$ By the eighteenth century the republic would enter a long period of decline both militarily and economically.

The Dutch Republic had a set of political institutions that seem peculiar by today's standards, but which in the past were common in many societies practicing collective governance. There was a central representative assembly to which individual provinces sent delegates. The distinctive feature of this system was that individual provinces had considerable authority to refuse to participate in collective efforts that they opposed. The provinces themselves had assemblies to which individual towns sent delegates, and here as well individual towns had considerable autonomy to refuse provincial decisions.

The institutions of the Dutch Republic were ideally designed to avoid autocratic rule by the center, but they were not well designed to deal with emergencies. This would become particularly apparent when the republic came into naval conflict with England during the latter part of the seventeenth century. Though the Dutch had considerably more wealth with which to construct a navy at this time, their decentralized pattern of decision making was not helpful. It took the Dutch Estates General until January 1654 to finally approve of financing a naval force that would have avoided defeat at the hands of the English in the summer of $1653 .{ }^{37}$ In many cases individual towns or individual provinces could simply refuse to pay for building ships and hiring crews. This was not a path to success, and the Dutch Republic would eventually succumb to the problems posed by its decentralized institutions.

\section{Option Three: Build Central State Capacity and Limit Emergency Power}

The third option for democracies is to acknowledge the importance of central state action but to build state capacity that can be used for prevention without having to resort to emergency powers. The democracies that have been most successful in combating COVID-19 have tended to take precisely this route.

Taiwan and South Korea have been two of the most successful democracies in containing the COVID-19 pandemic. On the face of it, this should seem very surprising given their proximity to and openness to travel to and from China. In spite of this, each of these two countries succeeded in containing COVID-19 without having to resort to the sort of lockdowns that Western democracies have been obliged to implement. Nor did the solutions implemented require emergency powers or legislation

In Taiwan, following the SARS outbreak of 2003 the government invested in the creation of a National Health Command Center that would integrate data sources and form response plans for future pandemics. When word was released on 31 December 
2019 of a case of pneumonia of unknown origin in Wuhan, China, the Taiwanese government was able to benefit from prior investments in prevention. Integration of the national health insurance database with customs and immigration as well as with cell phone data allowed for tracking, testing, and isolating individuals potentially exposed to COVID-19 without having to resort to a full-scale lockdown. ${ }^{38}$ This approach, which could not have been invented on the fly, was highly successful. It is true that this did involve citizens implicitly allowing government to have a large and unified set of data about them, but normal constitutional protections on the use of this information remained in place. It is also worth remembering that most citizens in the United States have already surrendered a great deal of data about themselves to tech companies without getting much of anything in return.

South Korea made its investments in preventive state capacity after the MERS outbreak of 2015, which was widely judged to have been poorly handled by the government at the time. New legislation was passed that allowed the ministry of health to remotely collect telecommunications data on individuals that could be used to trace and track potential cases of a new disease. ${ }^{39}$ The new law also allowed the ministry to require that health providers transmit information about potentially infected patients. Finally, the new law also gave citizens the right to be tested for a new disease with the testing cost borne by the government. In order to make implementation of all this feasible, the South Korean government needed to invest in new types of state capacity. As in the Taiwanese case, the Korean legislation did give the government new authority, but its focus was strictly limited.

\section{At the Ballot Box: Is an Ounce of Cure Worth a Pound of Prevention?}

The essence of option three is that it depends on investments in state capacity. The big question is where the incentive to make these investments will come from. Will voters in a democracy reward incumbents for preventive action even if the impact of the action is hard to see, or will they instead be more likely to reward leaders who act once the danger has already become clear?

Existing empirical evidence on the prevention versus cure question is not particularly promising. In the United States there is a clear pattern whereby voters reward incumbents at the ballot box when they provide spending for disaster relief. German evidence suggests that the electoral benefit from disaster relief can be long-lasting. This would all seem like a good thing were it not for the fact that there is no evidence that voters reward incumbents for making investments in disaster prevention. ${ }^{40}$ There are various interpretations for this finding. The most direct and compelling one is that it is a very hard inferential problem for voters to be able to

38. Wang et al. 2020.

39. $\operatorname{Kim} 2020$.

40. This is based on US evidence from Healy and Malhotra 2009. Evidence on US disaster relief is provided by the same authors. The German evidence on flood relief is from Bechtel and Hainmueller 2011. 
determine whether a specific investment in disaster prevention actually has the intended effect.

Anecdotal evidence on epidemics and US presidents supports the conclusions from the statistical evidence. It is not clear that any US president to date has been faulted for ignoring an epidemic, yet the one president who did try to do something was widely ridiculed for it. ${ }^{41}$ Woodrow Wilson did not do much with regard to the Spanish flu pandemic of 1918, yet suffered little criticism. The same can be said for Dwight Eisenhower's response to the Asian flu of 1957 as he emphasized private solutions over central government action.

The one president who did try to take decisive action in the face of an expected pandemic was widely ridiculed for it. ${ }^{42}$ We could call this the "Gerald Ford effect." In the winter of 1976 a new variant of influenza appeared that some thought to be closely related to the deadly Spanish flu of 1918 that killed millions. President Ford launched a heavily publicized effort to vaccinate the entire American population. In the end, the new influenza strain turned out to be far less deadly than imagined. As thanks for his preventive efforts, Ford was criticized by both the left and right of the political spectrum. The Gerald Ford effect applies in any situation where a democratic leader is ridiculed for investments in prevention that made sense at the time but turned out not to have been necessary in the end.

What could prompt voters to reward politicians for disaster prevention? One way might be for past occurrences to signal the risk of an occurrence in the future. It was after the MERS outbreak of 2015 that South Korea made investments in state capacity to deal with a future pandemic. After suffering an outbreak of the SARS coronavirus in 2002-2003, Taiwan's government invested in a complete revamp of the public health system. The interesting fact here is that by the standards of the COVID-19 pandemic, the number of SARS cases in Taiwan was very small. There were 665 confirmed cases and 180 deaths. ${ }^{43}$ So in this case one crisis prompted investment that helped prevent a much larger subsequent disaster from taking place. It has been argued that the SARS epidemic - which left the United States and Western Europe almost totally unaffected-played a role in prompting a number of East Asian governments to take the initial COVID-19 threat more seriously. It is possible that this effect could now take place in Western democracies if the public supports investment to prevent the next pandemic.

\section{Conclusion}

Democracies and autocracies face very different challenges when dealing with emergencies. In an autocracy the state faces fewer hurdles to decisive action, but this comes with a great risk: information about an emergency may be suppressed with 
the blame laid elsewhere. In a democracy it is hard to suppress information but also harder to take decisive action. Two of the ways in which democracies have tried to confront this problem have not worked particularly well. Granting emergency powers to the center has often resulted in their abuse. Simply leaving matters to the localities has come at the cost of ineffectiveness. The third route-building capacity for prevention while avoiding emergency power-has the most promise, but only if elected officials anticipate that they will actually be recognized for their efforts. We can only hope that the COVID-19 pandemic convinces ordinary voters, political elites, and elected officials that investments such as these are indeed worthwhile.

\section{References}

Barker, Randolph. 2012. The Origin and Spread of Early-Ripening Champa Rice: Its Impact on Song Dynasty China. Rice 4 (3):184-86.

Bechtel, Michael and Jens Hainmueller. 2011. How Lasting is Voter Gratitude? An Analysis of the Shortand Long-Term Electoral Returns to Beneficial Policy. American Journal of Political Science 55 (4): $852-68$

Bernstein, Lenny, and Tim Craig. 2020. Unprecedented Chinese Quarantine Could Backfire, Experts Say. Washington Post, January 24. Available at <https://www.washingtonpost.com/health/unprecedentedchinese-quarantine-could-backfire-experts-say/2020/01/24db073f3c-3ea4-11ea-8872-5df698785a4e_story.html>. Accessed 21 July 2020.

Billing, Lynzy. 2020. Duterte's Response to the Coronavirus: 'Shoot Them Dead.' Foreign Policy (blog). April 16. Available at <https://foreignpolicy.com/2020/04/16/duterte-philippines-coronavirus-responseshoot-them-dead/>. Accessed 21 July 2020.

Blake, Aaron. 2020. 49 of 50 Governors Have Better Coronavirus Poll Numbers than Trump. Washington Post, March 19. Available at <https://www.washingtonpost.com/politics/2020/05/19/49-50-governorshave-better-coronavirus-numbers-than-trump/>. Accessed 21 July 2020.

Bosancianu, Constantin Manuel, Kim Yi Dionne, Hanno Hilbig, Macartan Humphreys, Sampada KC, Niels Lieber, and Alexandra Scacco. 2020. Political and Social Correlates of COVID-19 Mortality. Working Paper.

Cheibub, José Antonio, Ji Yeon Jean Hong, and Adam Przeworski. 2020. Rights and Deaths: Government Reactions to the Pandemic. Working Paper.

De Vries, Jan, \& van der Woude, A. 1997. The First Modern Economy: Success, Failure, and Perseverance of the Dutch Economy, 1500-1815. Cambridge University Press.

Dunstan, Susan, 1975. The Late Ming Epidemics: A Preliminary Survey. Ch'ing-shih wen-t'i 3 (3):1-59.

Fazal, Tanisha. 2020. Health Diplomacy in Pandemical Times: Drifting Toward Bilateralism? International Organization 74 (S1). <https://doi.org/10.1017/S0020818320000326>

Fottrell, Quentin. 2020. Nurses Are Wearing Garbage Bags as They Battle Coronavirus: 'It's like Something out of the Twlight Zone.' Market Watch. April 13. Available at <https://www.marketwatch.com/story/nurse-at-brooklyn-hospital-on-coronavirus-protective-clothing-its-a-garbage-bag-itslike-something-out-of-the-twlight-zone-2020-04-07>. Accessed 21 July 2020.

Gensini Gian Franco, Magdi H. Yacoub, and Andrea A. Conti. 2004. The Concept of Quarantine in History: From Plague to SARS. Journal of Infection 49 (4):257-261.

Greitens, Sheena Chestnut. 2020. Surveillance, Security, and Democracy in a Post-COVID-19 World. International Organization 74 (S1). <https://doi.org/10.1017/S0020818320000417>

Hasell, Joe, and Max Roser. 2013. Famines. Our World in Data (Updated 2017). Available at $<$ https://ourworldindata.org/famines>. Accessed 21 July 2020. 
Healy, Andrew and Neil Malhotra. 2009. "Myopic Voters and Natural Disaster Policy." American Political Science Review 103 (3):387-406.

Ho, Ping-Ti. 1956. Early-Ripening Rice in Chinese History. The Economic History Review 9 (2):200-18.

Honig, Bonnie. 2009. Emergency Politics: Paradox, Law, and Democracy. Princeton: Princeton University Press.

Jisheng, Yang. 2012. Tombstone: The Great Chinese Famine, 1958-1962. Farrar, Straus, and Giroux.

Jones, J.R. 1988. The Dutch Navy and National Survival in the Seventeenth Century. International History Review 10 (1):18-32.

Jordan, William Chester. 1996. The Great Famine: Northern Europe in the Early Fourteenth Century. Princeton University Press.

Kim, Brian. 2020. Lessons for America: How South Korean Authorities Used Law to Fight the Coronavirus. Lawfare, March 16. Available at <https://www.lawfareblog.com/lessons-america-howsouth-korean-authorities-used-law-fight-coronavirus>. Accessed 21 July 2020.

Kupferschmidt, Kai, and Jon Cohen. 2020. Can China's COVID-19 Strategy Work Elsewhere? Science 367 (6482): 1061-62. Available at <https://doi.org/10.1126/science.367.6482.1061>. Accessed 21 July 2020.

Lazar, Nomi Claire. 2009. States of Emergency in Liberal Democracies. Cambridge University Press.

Lazar, Nomi Claire. 2006. Making Emergencies Safe for Democracy: The Roman Dictatorship and the Rule of Law in the Study of Crisis Government. Constellations 13 (4):506-21.

Manin, Bernard. 2008. The Emergency Paradigm and the New Terrorism: What if the End of Terrorism Was Not in Sight? Available at <https://as.nyu.edu/content/dam/nyu-as/faculty/documents/emerg. pdf>. Accessed 21 July 2020.

Nelson, Adam. 2020. Authoritarianism Is the Greatest Public Health Risk. The Hill. February 23. Available at <https://thehill.com/opinion/healthcare/484190-authoritarianism-is-a-public-health-risk>. Accessed 21 July 2020.

Ratcliffe, Rebecca. 2020. Fears as Cambodia Grants PM Vast Powers Under COVID-19 Pretext. The Guardian, April 10. Available at <https://www.theguardian.com/world/2020/apr/10/fears-as-cambodia-grants-hun-sen-vast-power-under-covid-19-pretext>. Accessed 27 July 2020.

Reiter, Dan and Allan Stam. 2020. Democracies Have an Edge in Fighting Wars: That Will Help Them Fight Diseases Too. Foreign Affairs, May 7, 2020.

Roache, Madeline. 2020. How Russia's Coronavirus Outbreak Became One of the World's Worst. Time, May 15. Available at <https://time.com/5836890/russia-coronavirus/>. Accessed 21 July 2020.

Roger, Euan. 2019. 'To Be Shut Up': New Evidence for the Development of Quarantine Regulations in Early-Tudor England. Social History of Medicine. <https://doi.org/10.1093/shm/hkz031>.

Rossiter, Clinton. 1948. Constitutional Dictatorship: Crisis Government in the Modern Democracies. Princeton University Press.

Schmitt, Carl. 2013 [1921]. Dictatorship. Polity Press.

Sen, Amartya. 1981. Poverty and Famines: An Essay on Entitlement and Deprivation. Oxford University Press.

Skidmore, Max. 2016. Presidents, Pandemics, and Politics. Palgrave Macmillan.

Smith, Alexander. 2020. Coronavirus: China's Xi Jinping Faces His Biggest Challenge. February 15. Available at <https://www.nbcnews.com/news/world/coronavirus-china-s-xi-jinping-faces-his-biggestchallenge-n1136851>. Accessed 21 July 2020.

Somers, R. 1979. The end of the T'ang. In The Cambridge History of China, edited by Denis Twitchett, 682-789. Cambridge University Press.

Stasavage, David. 2020. The Decline and Rise of Democracy: A Global History from Antiquity to Today. Princeton University Press.

Stelzenmüller, Constanze, and Sam Denney. 2020. COVID-19 Is a Severe Test for Germany's Postwar Constitution. Lawfare, April 16. Available at <https://www.lawfareblog.com/COVID-19-severe-testgermanys-postwar-constitution>. Accessed 21 July 2020.

Stephens, Bret. 2020. COVID-19 and the Big Government Problem. The New York Times. April 10. Available at <https://www.nytimes.com/2020/04/10/opinion/coronavirus-FDA.html>. Accessed 21 July 2020. 
Titova, Irina. 2020. Coronavirus: Russia Doctors Say Government Is Covering up Cases. Business Insider. March 20. Available at <https://www.businessinsider.com/coronavirus-russia-doctors-say-governmentis-covering-up-cases-2020-3>. Accessed 21 July 2020.

Wang, C. Jason, Chun Y. Ng, and Robert H. Brook. 2020. Response to COVID-19 in Taiwan: Big Data Analytics, New Technology, and Proactive Testing. JAMA 323 (14): 1341-42. Available at <https://doi. org/10.1001/jama.2020.3151>. Accessed 21 July 2020.

Wilson, Mark B. 2017. The Needed Man: The Evolution, Abandonment, and Resurrection of the Roman Dictatorship. Unpublished PhD Thesis, The Graduate Center, City University of New York.

World Health Organization (WHO). 2003. Summary table of SARS cases by country, 1 November 2002 -7 August 2003. Available at <https://www.who.int/csr/sars/country/2003_08_15/en/>. Accessed 21 July 2020.

Zerofsky, Elisabeth. 2020. How Viktor Orbán Used the Coronavirus to Seize More Power. The New Yorker. April 9. Available at <https://www.newyorker.com/news/letter-from-europe/how-viktororban-used-the-coronavirus-to-seize-more-power>. Accessed 21 July 2020.

\section{Author}

David Stasavage is Dean for the Social Sciences and Julius Silver Professor of Politics at New York University. He can be reached at david.stasavage@nyu.edu.

\section{Acknowledgments}

I would like to thank Sheena Chestnut Greitens, the editors, and participants at an $I O$ and Penn Perry World House conference for comments and suggestions on a previous draft.

\section{Key Words}

democracy; autocracy; COVID-19 